\title{
PREDIKSI KEBANGKRUTAN MODEL SPRINGATE PADA INDUSTRI TELEKOMUNIKASI
}

\author{
Riani Fifrianti ${ }^{1,}$ Perdana Wahyu Santosa ${ }^{2}$ \\ perdana.wahyu@yarsi.ac.id \\ Program Studi Akuntansi Universitas YARSI \\ Program Magister Manajemen Universitas YARSI
}

Received: 15 Maret 2018

Final Acepted: 25 April 2018

Published Online: Juni 2018

Keywords:

Telecommunication, Financial

Distress, Bankruptcy, Prediction,

Springate

Corresponding Authors:

* Perdana Wahyu Santosa

\begin{abstract}
This study purposes to analyze of corporate bankruptcy prediction of telecommunication industry in Indonesia with Springate model. The data used in the form of financial statements published by the telecommunications industry at Indonesia Stock Exchange for 2009-2013 period. The sampling technique of this study was determined by purposive sampling method for six samples from Indonesia Stock Exchange (IDX). The results using Springate model shows that two companies, PT Bakrie Telecom, Tbk and PT Smartfren, Tbk could potentially bankrupt in the future and three companies For PT Indosat, Tbk, PT XL Axiata, Tbk and PT Inovisi Infracom, Tbk are classified have financial distress problem. The company that very good results is PT Telekom Indonesia, Tbk and categorized has no bankruptcy problem. In general analysis telecommunication caompany have no good financial condition because business risk and financial risk are higher relatively than other industry.
\end{abstract}

Copyright JEBA 2018., All rights reserved

\begin{abstract}
ABSTRAK
Penelitian ini bertujuan untuk menganalisis dan membandingkan prediksi kebangkrutan perusahaan-perusahaan di sector telekomunikasi dengan menggunakan model Springate. Data yang digunakan berupa laporan keuangan industri telekomunikasi yang dipublikasikan di Bursa Efek Indonesia (IDX) periode 2009-2013. Teknik pengambilan sampel penelitian menggunakan purposive sampling sesuai kriteria penelitian dan didapat 6 emiten di Bursa Efek Indonesia. Hasil penelitian yang menggunakan metode Springate menunjukkan ada dua perusahaan berpotensi bangkrut yaitu PT Bakrie Telecom, Tbk dan PT Smartfren, Tbk. Sedangkan PI Indosat, Tbk, PT XL Axiata, Tbk dan PT Inovisi Infracom, Tbk masih memiliki potensi financial distress dan kebangkrutan, namun sejauh ini masih terkendali. Sedangkan PT Telkom Indonesia, Tbk tergolong tidak berpotensi mengalami kebangkrutan. Secara umum perusahaan telekomunikasi mengalami masalah finansial karena risiko bisnis dan finansial yang relatif tinggi dibandingkan industri lainnya.
\end{abstract}

Kata kunci: Telekomunikasi, Financial Distress, Kebangkrutan, Prediksi, Springate 


\section{PENDAHULUAN}

Industri telekomunikasi adalah industri yang memiliki tingkat persaingan yang tinggi dan membentuk pasar oligopoli dan highly regulated. Industri ini juga sangat tergantung kepada kecanggihan teknologi terutama teknologi informasi dan komunikasi terbaru (high-end). Selain itu, industri telekomunikasi juga kental dengan nuansa politik karena dinilai memiliki peran strategis terhadap aspek sosial, politik dan perekonomian nasional. Pemerintah juga memiliki saham di dua perusahaan raksasa telekomunikasi yaitu PT Telekomunikasi Indonesia, Tbk dan PT Indosat, Tbk. Dengan struktur industri yang cukup rumit ini maka tidak heran jika industri ini dikenal sebagai salah satu industri dengan tingkat persaingan yang sangat tinggi.

Industri telekomunikasi juga dikenal termasuk sektor yang berisiko tinggi terutama dari sisi risiko bisnisnya. Hal ini disebabkan telekomunikasi membutuhkan investasi (capital expendinture) yang besar, perkembangan teknologi yang sangat pesat, persaingan yang semakin tajam serta perubahan selera pelanggan yang dinamis terutama dari generasi milenial. Sebagai contoh kasus perusahaan yang mengalami financial distress adalah PT. Axis Telekom Indonesia yang melakukan merger dengan XL, seperti yang dikutip pada tribunnews.com (2014), CEO PT. Axis mengatakan bahwa merger dan akuisisi Axis oleh XL merupakan langkah tepat untuk mengatasi kesulitan keuangan operasional perusahaan. Tiap tahun, Axis rugi Rp 2,3 triliun dan sempat menunggak pembayaran kewajiban BHP Frekuensi. Setelah ada persetujuan aksi korporasi tersebut, Axis akhirnya bersedia melunasi BHP senilai Rp 1 triliun pada akhir Desember 2013.

Tingginya persaingan di industri telekomunikasi menyebabkan terjadinya perang harga/tarif pulsa yang sering mengakibatkan kerugian pemain-pemainnya sendiri. Beberapa perusahaan terindikasi mengalami masalah finansial hingga berpotensi bangkrut (bankruptcy). Secara umum, gejala awal kebangkrutan biasanya ditandai dengan kesulitan keuangan yang dialami oleh perusahaan dalam bentuk likuiditas dan arus kas yang negatif di mana perusahaan tidak mampu memenuhi kewajiban jangka pendeknya (current liabilities) akibat keringnya modal kerja. Jika kesulitan keuangan tersebut tidak segera ditangani oleh manajemen, maka akan berlanjut menjadi masalah solvabilitas yang terkait dengan kewajiban pendaan jangka panjang terutama pinjaman bank dan obligasi korporasi. 
Apabila tidak dapat ditangani maka gejala kebangkrutan dan financial distress perusahaan sehingga dapat dilikuidasi (Fithri, 2010).

Masalah dari sisi internal dan eksternal perusahaan merupakan dua masalah penting yang memicu kebangkrutan pada sebuah perusahaan. Menurut Fithri (2010), masalah dari sisi internal, biasanya disebabkan karena strategi yang diterapkan manajemen tidak sesuai dengan kondisi pasar, atau pihak manajemen yang kurang teliti memperhatikan perubahan pasar yang semakin berkembang, sehingga keuntungan yang didapatkan perusahaan tidak bisa menutupi kewajibannya. Sedangkan masalah dari sisi eksternal, biasanya dipicu oleh kondisi perekonomian di Indonesia maupun di dunia yang masih belum menentu. Hal ini menjadi penyebab tingginya risiko suatu perusahaan untuk mengalami kesulitan keuangan atau bahkan kebangkrutan jika perusahaan tersebut tidak siap menghadapi kondisi yang berkembang saat ini.

Untuk itu kami telah menganalisis prediksi kebangkrutan untuk industri telekomunikasi sebagai panduan bagi para investor yang menanamkan modalnya di ekuitas atau obligasi telekomunikasi. Laporan keuangan yang diterbitkan oleh perusahaan merupakan salah satu sumber informasi mengenai posisi keuangan perusahaan, kinerja serta perubahan posisi keuangan perusahaan, yang sangat berguna untuk mendukung pengambilan keputusan yang tepat. Data keuangan pada laporan keuangan bermanfaat untuk melihat kondisi kesehatan keuangan perusahaan. Adapun permasalahan yang dianalisis meliputi analisis perbandingan prediksi kebangkrutan model Springate pada sektor telekomunikasi.

\section{KAJIAN TEORI}

Perusahaan dikategorikan gagal secara finansial jika perusahaan tersebut tidak mampu membayar kewajibannya pada waktu jatuh tempo meskipun total aktiva melebihi total kewajibannya (Subrahmanyan dan Wild, 2010). Jatuh bangunnya perusahaan merupakan hal yang biasa karena pengaruh lingkungan bisnis yang turbulen, baik politik, ekonomi, sosial, maupun teknologi. Perusahaan selalu menghadapi berbagai risiko terutama risiko bisnis dan risiko finansial yang kerap membuat financial distress yang dapat mengarah pada kebangkrutan (Van Horne \& Wachowicz, 2009). Kepailitan atau kebangkrutan suatu perusahaan biasanya diawali dengan kesulitan keuangan (financial 
distress) yang ditandai oleh adanya ketidakpastian profitabilitas pada masa yang akan datang. Prediksi tentang kondisi keuangan perusahaan, yang berkaitan dengan kepailitan, merupakan informasi penting bagi pemangku kepentingan (stakeholders), yakni kreditor, investor, otoritas pembuat peraturan, auditor, dan manajemen (Butet, 2012).

Financial distress merupakan tahapan penurunan kondisi keuangan suatu perusahaan sebelum terjadinya kebangkrutan (Platt dan Platt, 2002). Untuk itu, pengenalan lebih awal kondisi perusahaan yang mengalami financial distress menjadi penting dilakukan. Informasi lebih awal kondisi financial distress pada perusahaan memberikan kesempatan bagi manajemen, pemilik, investor, regulator, dan para stakeholders lainnya untuk melakukan upaya-upaya yang relevan. Manajemen dan pemilik berkepentingan untuk melakukan upaya-upaya mencegah kondisi yang lebih parah kearah kebangkrutan. Investor berkepentingan dalam mengambil keputusan investasi atau divestasi. Regulator seperti Bank Indonesia (BI) dan Otoritas Jasa Keuangan (OJK) dalam melakukan pengawasan usaha.

Springate model merupakan model prediksi kebangkrutan perusahaan yang dikembangkan oleh Gordon Springate (1978) menggunakan analisis multidiskriminan, dengan menggunakan 40 perusahaan sebagai sampelnya. Model ini dapat digunakan untuk memprediksi suau financial distress dengan tingkat keakuratan 92,5\%. Dengan model yang sama, Botheras (1979) mendapatkan hasil dengan tingkat keakuratan 88\%. Sands (1980) melakukan pengujian dengan tingkat keakuratan mencapai 83\% (Fanny dan Saputra 2000). The Springate Model (S-Score) menggunakan analisis multidiskriminan, dengan variabel Working Capital to Total Assets, Net Profit Before Interest and Taxes to Total Assets, Net Profit Before Taxes to Current Liabilities, dan Sales to Total Assets (Syamsul dan Atika, 2008).

Kondisi financial distress dapat dikenali lebih awal sebelum terjadinya dengan menggunakan suatu model sistem peringatan dini (early warning system). Model ini dapat digunakan sebagai alat untuk mengenali gejala awal kondisi financial distress untuk selanjutnya dilakukan upaya memperbaiki kondisi sebelum sampai pada kondisi krisis atau kebangkrutan. Sejak dulu, telah ada beberapa peneliti yang mengembangkan model prediksi yang mencoba membantu calon-calon investor dan kreditur dalam memilih perusahaan tempat menaruh dana supaya tidak terjebak dalam masalah financial distress 
tersebut. Model-model tersebut antara lain dikemukakan oleh Altman (1968), Springate (1978), Ohlson (1980), dan Zmijewski (1983).

\section{Model Springate}

Model Springate dikembangkan oleh Gordon Springate (1978) dengan mengikuti prosedur yang digunakan oleh Altman (1968). Dengan mengikuti prosedur yang dikembangkan Altman, Springate mengunakan step-wise multiple discriminate analysis untuk memilih empat dari 19 rasio keuangan yang popular sehingga dapat membedakan perusahaan yang berada dalam zona bangkrut atau zona aman (Ayu, 2008). Model Springate merumuskan sebagai berikut :

$$
S=1.03 X_{1}+3.07 X_{2}+0.66 X_{3}+0.4 X_{4}
$$

Keterangan :

$$
\begin{aligned}
& \mathrm{S}=\text { Skor Springate } \\
& \mathrm{X}_{1}=\text { Working Capital/Total Assets } \\
& \mathrm{X}_{2}=\text { Net Profit Before Interest and Taxes/Total Assets } \\
& \mathrm{X}_{3}=\text { Net Profit Before Taxes/Current Liabilities } \\
& \mathrm{X}_{4}=\text { Sales/Total Assets }
\end{aligned}
$$

Springate (1978) mengemukakan nilai cut-off yang berlaku untuk model ini adalah 0,862. Skor S yang lebih kecil dari 0,862 menunjukkan bahwa perusahaan tersebut diprediksi akan mengalami financial distress hingga kebangkrutan. Model ini memiliki akurasi prediksi yang sangat tinggi yaitu 92,5\%. Dari hasil perhitungan model Springate diperoleh nilai S-Score yang dibagi dalam dua kategori sebagai berikut:

a. Jika nilai $\mathrm{S}>0,862$ maka perusahaan termasuk dalam kategori tidak pailit.

b. Jika nilai $\mathrm{S}<0,862$ maka perusahaan termasuk dalam kategori pailit.

\section{Penelitian Terdahulu}

Penelitian yang dilakukan oleh Harnanta dan Idhe (2013), menghasilkan bahwa hasil pengujian menggunakan metode Altman Z-Score diperoleh hasil selama periode 2008-2011, hanya PT Telkom Tbk yang dinyatakan sehat. Sedangkan untuk PT Indosat Tbk dan PT Bakrie Telecom Tbk hanya pada tahun 2008 berada pada grey area, tetapi periode 2009-2011 berada pada area kebangkrutan. Sedangkan untuk PT. XL Axiata Tbk 
pada tahun 2008 dinyatakan berada pada area bangkrut, tahun 2009 dikategorikan sehat tetapi pada 2010 dan 2011 masuk ke grey area. Sedangkan pengujian dengan menggunakan metode Springate, PT Telkom Tbk. selama periode 2008- 2011 dinyatakan berada diarea sehat. Untuk PT XL Axiata Tbk hanya pada periode 2009 masuk area sehat tetapi pada periode lainnya masuk area bangkrut. Sedangkan untuk PT. Indosat Tbk dan PT Bakrie Telecom berada pada area bangkrut selama periode 2008-2011.

Selanjutnya, Kokyung dan Khairani (2013), menemukan fakta bahwa PT.Bakrie Telecom Tbk tahun 2009-2012 menyatakan bahwa perusahaan mengalami penurunan kinerja yang signifikan. Hal ini diperkuat dengan hasil analisis kebangkrutan metode Altman Z-score yang menunjukkan keadaan bangkrut atau adanya masalah keuangan yang serius pada tahun 2012. Dari hasil analisis prediksi kebangkrutan yang dilakukan pada PT.Bakrie Telecom Tbk tahun 2009-2012 menyatakan bahwa perusahaan mengalami ancaman kebangkrutan dari tahun 2009-2012. Hal ini diperkuat dengan analisis kebangkrutan metode Springate yang menunjukkan keadaan bangkrut dari tahun 20092012.

Penelitian yang dilakukan oleh Thamrin Irawan (2013), selama 4 (empat) tahun periode, menyatakan bahwa nilai Z-Score yang dimiliki oleh perusahaan Telekomunikasi berfluktuasi dari tahun ke tahun dengan nilai $\mathrm{Z}<1,81$. Dan menggunakan nilai tren yang merupakan sebuah forecasting atau prakiraan di masa yang akan datang, sehingga untuk kenyataan nilai-nilai tersebut mungkin bisa mengalami kenaikan dan penuruan dari nilai $\mathrm{Z}$ yang terjadi untuk 5,7 dan 9 tahun ke depan. Dan dari hasil penelitian pada metode Analisis Altman Z-Score dapat diterapkan untuk meprediksi potensi adanya masalah kesehatan keuangan suatu perusahaan di Indonesia.

\section{Kerangka Konsep}

Penelitian ini dimaksudkan untuk melakukan pengujian mengenai prediksi kebangkrutan perusahaan dengan metode Springate pada perusahaan telekomunikasi yang terdaftar di Bursa Efek Indonesia periode 2009-2013. Berdasarkan pada kajian teoritis terdahulu maka analisis financial distress dan kebangkrutan yang disajikan pada Gambar 1 berikut ini: 


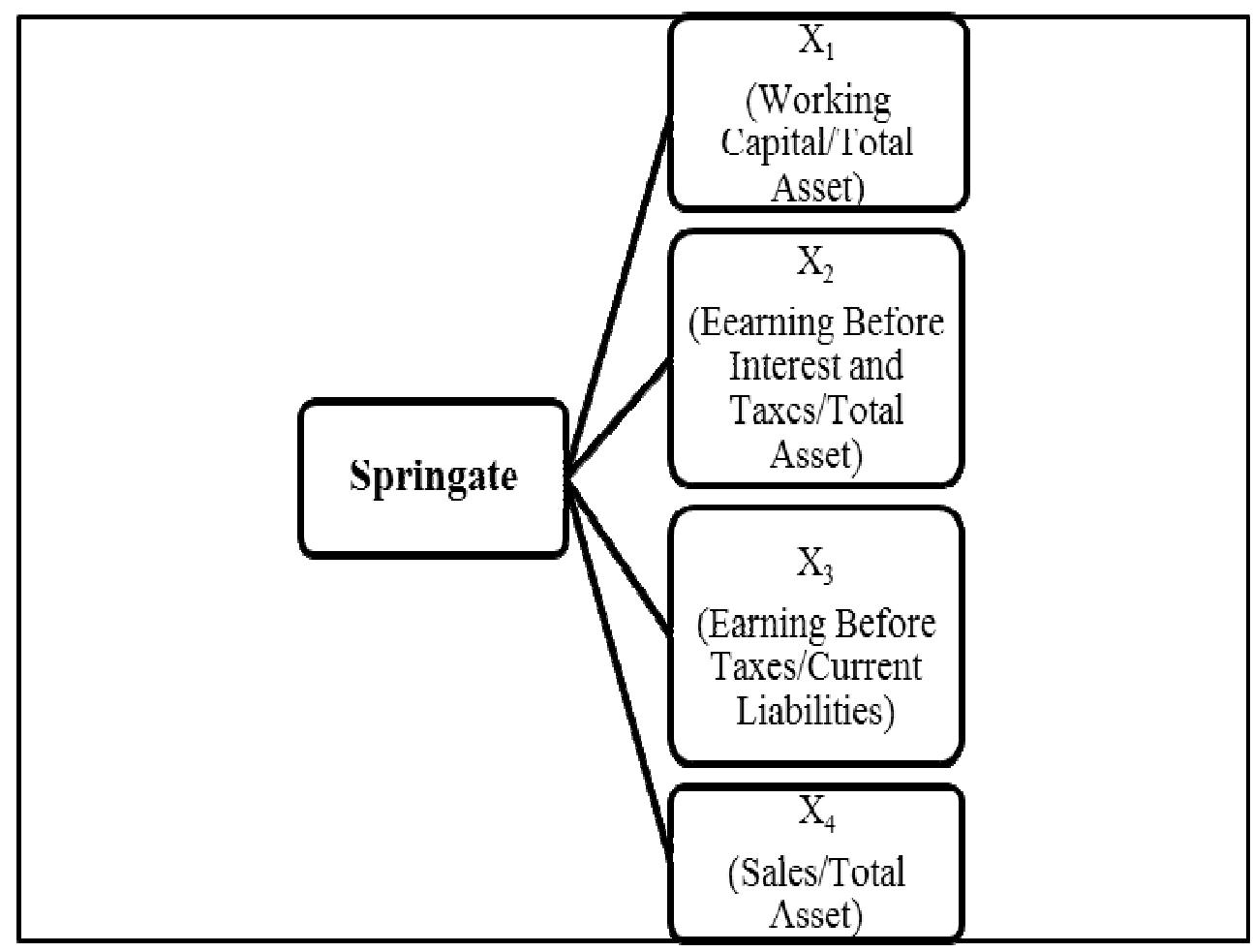

Gambar 1. Analisis Model Springate

\section{METODE PENELITIAN}

\section{Populasi dan Sampel}

Populasi dalam penelitian ini adalah semua perusahaan telekomunkasi yang terdaftar di Bursa Efek Indonesia periode 2009-2013. Sedangkan pemilihan sampel penelitian ini ditentukan secara purposive sampling dengan tujuan untuk mendapatkan sampel yang representatif sesuai dengan kriteria yang telah ditentukan. Kriteria yang yang ditentukan terdiri dari kriteria umum dan khusus.

Kriteria umum merupakan kriteria yang harus dipenuhi semua sampel, yaitu:

1) Data keuangan (laporan laba rugi, neraca, dan arus kas) tersedia dengan lengkap tahun 2009-2013.

2) Data harga saham tersedia pada tanggal perdagangan terakhir di tahun bersangkutan. 


\section{Metode Analisis Acuan Springate}

Nilai cut-off yang digunakan pada model Springate yaitu $\mathbf{0 . 8 6 2}$, yang berarti jika sebuah perusahaan memiliki $S$-Score lebih dari 0.862 maka perusahaan tersebut dianggap sehat atau tidak berpotensi mengalami kebangkrutan. Namun apabila perusahaan memiliki $S$ Score kurang dari 0.862 , maka perusahaan tersebut memiliki potensi mengalami financial distress atau kebangkrutan. Maka dengan semakin rendah nilai S-Score, perusahaan semakin dalam kondisi yang semakin parah keuangannya, begitu pula sebaliknya.

\section{HASIL DAN PEMBAHASAN}

\section{Model Analisis Kebangkrutan Model Springate \\ PT Bakrie Telecom, Tbk (BTEL)}

Berdasarkan hasil analisis metode Springate pada BTEL periode 2009-2013, dapat dilihat hasil olah data di bawah ini:

Tabel 1. Hasil Analisis Springate PT Bakrie Telecom, Tbk.

\begin{tabular}{cccccc}
\hline Tahun & WCTA $\left(X_{1}\right)$ & EBITTA $\left(X_{2}\right)$ & EBTCL $\left(X_{3}\right)$ & SATA $\left(X_{4}\right)$ & Springate \\
\hline 2009 & $-0,0264$ & 0,0244 & 0,0707 & 0,3007 & 0,2148 \\
2010 & $-0,0262$ & 0,0154 & 0,0526 & 0,2791 & 0,1668 \\
2011 & $-0,1644$ & $-0,0142$ & $-0,3342$ & 0,2616 & $-0,3290$ \\
2012 & $-0,2326$ & $-0,0553$ & $-1,2293$ & 0,3530 & $-1,0794$ \\
2013 & $-0,5197$ & 0,0004 & $-0,5729$ & 0,3501 & $-0,7721$
\end{tabular}

Sumber: BEI, data diolah

Hasil analisis metode springate pada PT Bakrie Telecom periode 2009-2013, terlihat bahwa adanya penurunan nilai $X_{1}$ yang berarti terjadi penurunan likuiditas pada perusahaan ini yang mengakibatkan penurunan kemampuan memenuhi kewajiban jangka pendeknya. Hal tersebut karena modal kerja bersih perusahaan yang selalu negatif bahkan semakin parah. Untuk nilai $X_{2}$ yang menunjukkan kemampuan menciptakan laba operasi juga semakin rendah bahkan sempat negatif pada 2011 dan 2012. Menurunnya laba operasi 
mengindikasikan rendahnya kemampuan BTEL dalam membayar kewajiban bunga pinjaman karena masalah arus kas.

Untuk nilai EBIT/CL $\left(X_{3}\right)$ pada perusahaan ini turun dari tahun 2009 hingga 2012, tapi kembali sedikit 2013 walaupun nilainya masih negatif, hal ini menunjukkan bahwa terjadinya penurunan profitabilitas perusahaan di mana laba bersih juga semakin berkurang dan negatif. Selanjutnya diukur dari sisi efisiensi yaitu asset turover $\left(X_{4}\right)$ selalu menunjukkan rasio yang sangat rendah bahkan di bawah satu hal ini menunjukkan bahwa kemampuan perusahaan dalam menciptakan penjualan dengan asset yang ada sangat minim.

Selanjutnya, untuk nilai dari metode springate pada perusahaan ini periode 2009 hingga 2013 berpotensi bangkrut karena nilai Z-score yang selalu di bawah cut off $(0,862)$. Bahkan secara konstan nilainya terus menurun hingga menjadi negatif yang menunjukkan masalah finansial BTEL ini semakin parah dan menuju kebangkrutan.

\section{PT Smartfren, Tbk (FREN).}

Berdasarkan hasil analisis metode springate pada PT Smartfren, Tbk periode 2009-2013, dapat dilihat hasil olah data di bawah ini:

Tabel 2. Hasil Analisis Springate PT Smartfren Tbk.

\begin{tabular}{cccccc}
\hline Tahun & WCTA $\left(\boldsymbol{X}_{1}\right)$ & EBITTA $\left(\boldsymbol{X}_{2}\right)$ & EBTCL $\left(\boldsymbol{X}_{3}\right)$ & SATA $\left(X_{4}\right)$ & Springate \\
\hline 2009 & $-0,1535$ & $-0,1420$ & $-0,5316$ & 0,1061 & $-0,9024$ \\
2010 & $-0,3632$ & $-0,1935$ & $-0,6572$ & 0,0840 & $-1,3682$ \\
2011 & $-0,1875$ & $-0,1807$ & $-0,8548$ & 0,0776 & $-1,2808$ \\
2012 & $-0,1519$ & $-0,1118$ & $-0,5977$ & 0,1150 & $-0,8480$ \\
2013 & $-0,2222$ & $-0,1015$ & $-0,4889$ & 0,1531 & $-0,8020$ \\
\hline
\end{tabular}

Sumber: BEI, data diolah

Hasil analisis metode springate pada PT Smartfren Tbk periode 2009 sampai dengan 2013, diperoleh hasil bahwa nilai likuiditas $\left(X_{1}\right)$ pada perusahaan ini selalu negatif dan cenderung semakin buruk, hal ini berarti kemampuan FREN memenuhi kewajiban jangka pendeknya semakin buruk setiap tahunnya. Nilai $X_{2}$ pada perusahaan ini juga selalu negatif, dan cenderung naik turun, hal ini juga berarti bahwa terjadinya pelemahan 
kemampuan aset perusahaan untuk menghasilkan laba operasi (laba dari aktiva perusahaan).

Untuk kemampuan EBIT dibanding kewajiban lancar $\left(X_{\mathrm{a}}\right)$ juga selalu negatif dan berfluktasi di area minus pada periode 2009-2011. Kondisi tersebut menunjukkan bahwa perusahaan sudah tak memiliki kemampuan memenuhi kewajiban lancarnya. Sedangkan untuk tingkat efisiensi aset $\left(X_{4}\right)$, skor perusahaan ini juga selalu menurun yang menunjukkan kondisi operasional bisnis yang semakin parah.

Sementara itu, nilai dari metode springate untuk perusahaan ini sepanjang periode 2009-2013 selalu negatif dan menurun jauh di bawah cut off Springate yaitu 0,862. Hal ini menunjukkan perusahaan berpotensi mengalami kebangkrutan yang disebabkan oleh penurunan pendapatan, laba bersih dan arus kas yang negatif akibat meningkatnya risiko bisnis dan risiko financial yang tak dapat dikelola dengan baik.

\section{PT XL Axiata, Tbk (EXCL).}

Berdasarkan hasil analisis metode springate pada PT XL Axiata, Tbk periode 2009 sampai dengan 2013, dapat dilihat hasil olah data di bawah ini:

Tabel 3. Hasil Analisis Springate PT XL Axiata Tbk.

\begin{tabular}{cccccc}
\hline Tahun & WCTA $\left(\boldsymbol{X}_{\mathbf{1}}\right)$ & EBITTA $\left(\boldsymbol{X}_{2}\right)$ & EBTCL $\left(\boldsymbol{X}_{\mathbf{3}}\right)$ & SATA $\left(\boldsymbol{X}_{\mathbf{4}}\right)$ & Springate \\
\hline 2009 & $-0,1462$ & 0,0900 & 0,3933 & 0,5069 & 0,5880 \\
2010 & $-0,0857$ & 0,1895 & 0,8477 & 0,6472 & 1,3119 \\
2011 & $-0,1713$ & 0,1240 & 0,4428 & 0,5858 & 0,7307 \\
2012 & $-0,1433$ & 0,1228 & 0,4292 & 0,5914 & 0,7491 \\
2013 & $-0,0518$ & 0,0412 & 0,1752 & 0,5280 & 0,3999 \\
\hline
\end{tabular}

Sumber: BEI, data diolah

Hasil analisis metode springate pada PT XL Axiata Tbk periode 2009 sampai dengan 2013, terlihat bahwa nilai modal kerja terhadap total aset $\left(X_{1}\right)$ berfluktuasi selama periode tersebut, ini berarti bahwa likuiditas perusahaan tidak stabil dan selalu tercatat negatif. Hal ini menujukkan bahwa likuiditas EXCL sangat buruk sehingga tidak mampu memenuhi kewajiban jangka pendeknya. Untuk rasio laba operasi (EBIT) dibanding total aset $\left(X_{2}\right)$ menunjukkan nilai positif namun nilainya relatif kecil dan menurun, hal ini 
menunjukkan bahwa terjadinya penurunan kemampuan dari aktiva perusahaan untuk menghasilkan laba operasi (laba dari aktiva perusahaan) dari 2010-2013.

Selanjutnya untuk nilai EBT/CL $\left(X_{3}\right)$ pada perusahaan ini secara umum positif sehingga EXEL dinilai masih mampu memenuhi kewajiban lancarnya dari laba operasionalnya. Namun rasio ini juga cenderung menurun hal ini menunjukkan bahwa terjadinya penurunan profitabilitas terutama periode 2011-2013. Untuk efisiensi aset $\left(X_{4}\right)$ dari perusahaan ini cukup baik sekalipun masih di bawah satu. Secara umum efisiensi aset cukup stabil pada kisaran 0,5 dan berfluktuasi setiap tahunnya.

Sementara itu, untuk nilai metode springate, perusahaan ini cenderung mengalami financial distress dan kebangkrutan, kecuali di tahun 2010. Manajemen XL Axiata dinilai belum mampu meningkatkan profitabilitas perusahaan secara signifikan sehingga kerap timbul masalah likuiditas dan solvabilitas.

\section{PT Inovisi Infracom Tbk.}

Berdasarkan hasil analisis metode springate pada PT Inovisi Infracom, Tbk periode 2009 sampai dengan 2013, dapat dilihat hasil olah data di bawah ini:

Tabel 4. Hasil Analisis Springate PT Inovisi Infracom Tbk

\begin{tabular}{cccccc}
\hline Tahun & WCTA $\left(X_{1}\right)$ & EBITTA $\left(X_{2}\right)$ & EBTCL $\left(X_{3}\right)$ & SATA $\left(X_{4}\right)$ & Springate \\
\hline 2009 & 0,2275 & 0,0113 & 0,4706 & 0,4774 & 0,7706 \\
2010 & $-0,0697$ & 0,0904 & 0,7043 & 0,2945 & 0,7882 \\
2011 & 0,2233 & 0,0506 & 0,9005 & 0,2097 & 1,0638 \\
2012 & 0,2538 & 0,0856 & 0,8648 & 0,3850 & 1,2490 \\
2013 & 0,1162 & 0,0621 & 0,2571 & 0,3632 & 0,6252 \\
\hline
\end{tabular}

Sumber: BEI, data diolah

Hasil analisis metode springate pada PT Inovisi Infracom, Tbk periode 20092013, terlihat bahwa nilai $X_{1}$ pada perusahaan ini berfluktuasi dari 2009 hingga 2013, meskipun pada 2010 menunjukkan nilai yang negatif, dan kembali bernilai positif di 20112013. Secara umum likuiditas perusahaan cukup baik dan terkendali sehingga selalu memiliki kemampuan untuk memenuhi kewajiban lancarnya. Indikator EBIT/TA $\left(X_{2}\right)$ pada perusahaan ini secara umum juga cukup baik dan selalu positif. Hal ini menunjukkan kemampuan profitabilitas yang cukup baik. . 
Selanjutnya, rasio EBT/CL $\left(X_{3}\right)$ pada perusahaan ini juga cukup baik dan selalu positif yang menunjukkan bahwa kemampuan laba operasi setelah bunga perusahaan dapat menutup semua kewajiban lancarnya dengan baik. Namun pada 2012-2013 mengalami penurunan, kondisi tersebut disebabkan dalam 2 tahun terakhir perusahaan ini mengalami penurunan profitabilitasnya. Selanjutnya nilai $X_{4}$ pada metode ini mengalami penurunan dari 2009 sampai 2011, kemudian naik pada 2012 dan turun beberapa poin di tahun 2013, hal ini berarti bahwa terjadi penurunan mengenai kemampuan perusahaan dalam menciptakan penjualan dengan asset yang ada pada tahun 2013.

Untuk nilai metode springate pada perusahaan ini, memiliki potensi financial distress dan kebangkrutan pada 2009, 2010, dan 2013 namun tidak terlalu serius. Sementara pada tahun 2011-2012 perusahaan dalam kondisi aman keuangannya. Manajemen diharapkan mampu meningkatkan kemampuan profitabilitas, likuiditas dan solvabilitas perusahaan agar menjauh dari zona kebangkrutan.

\section{PT Indosat, Tbk.}

Berdasarkan hasil analisis metode Springate yang dilakukan pada PT Indosat, Tbk periode 2009-2013, dapat dilihat hasil olah data di bawah ini:

Tabel 5. Hasil Analisis Springate PT Indosat, Tbk.

\begin{tabular}{cccccc}
\hline Tahun & WCTA $\left(X_{1}\right)$ & EBITTA $\left(X_{2}\right)$ & EBTCL $\left(X_{3}\right)$ & SATA $\left(X_{4}\right)$ & Springate \\
\hline 2009 & $-0,1078$ & 0,0584 & 0,1708 & 0,3420 & 0,3177 \\
2010 & $-0,1096$ & 0,0658 & 0,0906 & 0,3748 & 0,2987 \\
2011 & $-0,1033$ & 0,0607 & 0,1112 & 0,3935 & 0,3106 \\
2012 & $-0,0490$ & 0,0578 & 0,0419 & 0,4060 & 0,3169 \\
2013 & $-0,1160$ & 0,0277 & 0,2471 & 0,4112 & 0,2930 \\
\hline
\end{tabular}

Sumber: BEI, data diolah

Berdasarkan hasil analisis metode Springate yang dilakukan pada PT Indosat, Tbk (ISAT) periode 2009-2013, terlihat bahwa nilai likuiditas $\left(X_{1}\right)$ pada perusahaan ini cenderung negatif dan fluktuatif, yang berarti bahwa likuiditas perusahaan selalu kurang baik dan berpotensi mengalami financial distress. Kemudian, rasio EBIT/CL $\left(X_{2}\right)$ pada perusahaan ini secara umum positif dan berfluktuasi pada kisaran 0,05-0,06 kecuali untuk 
2013 yang jatuh hingga 0,0277. Hal ini mengindikasikan bahwa mengalami penurunan EBIT yang cukup besar sehingga perusahaan harus lebih hati-hati lagi.

Selanjutnya untuk nilai $X_{3}$ pada perusahaan atau rasio EBT/CL selalu positif sehingga perusahaan cukup memiliki kemampuan untuk menutup kewajiban lancarnya setiap tahunnya. Nilai $X_{4}$ pada perusahaan ini naik di setiap tahunnya, hal ini menunjukkan bahwa kemampuan perusahaan dalam menciptakan penjualan dengan asset yang ada cukup baik dan terus meningkat.

Sementara itu nilai dari metode springate untuk perusahaan ISAT ini, dari setiap tahunnya berpotensi mengalami kebangkrutan karena selalu di bawah z-score 0,862. Perusahaan terindikasi mengalami financial distress yang cukup akut/parah dan berlarutlarut sehingga berpotensi terjerumus ke zona kebangkrutan.

\section{PT Telekomunikasi Indonesia Tbk.}

Berdasarkan hasil analisis metode Springate yang dilakukan pada PT Telekomunikasi Indonesia, Tbk (Telkom) periode 2009-2013, dapat dilihat hasil olah data di bawah ini:

Tabel 6. Hasil Analisis Springate PT Telekomunikasi Indonesia, Tbk

\begin{tabular}{cccccc}
\hline Tahun & WCTA $\left(X_{1}\right)$ & EBITTA $\left.X_{2}\right)$ & EBTCL $\left(X_{3}\right)$ & SATA $\left(X_{\mathbf{4}_{\mathbf{s}}}\right)$ & Springate \\
\hline 2009 & $-0,1097$ & 0,2336 & 0,8347 & 0,6937 & 1,4324 \\
2010 & $-0,0175$ & 0,2255 & 1,0461 & 0,6880 & 1,6397 \\
2011 & $-0,0090$ & 0,2131 & 0,9400 & 0,6914 & 1,5418 \\
2012 & 0,0347 & 0,2307 & 1,0050 & 0,6927 & 1,6845 \\
2013 & 0,0362 & 0,2176 & 0,9547 & 0,6484 & 1,5949 \\
\hline
\end{tabular}

Sumber: BEI, data diolah

Berdasarkan hasil analisis metode Springate yang dilakukan pada PT Telekomunikasi Indonesia,Tbk rasio likuiditas $\left(X_{1}\right)$ mengalami penurunan dari 2009 hingga 2011 dan bernilai negatif, tetapi pada tahun 2012 kembali positif, hal ini berarti bahwa masalah likuiditas TLKM sudah teratasi sehingga kembali memiliki kemampuan untuk memenuhi kewajiban jangka pendeknya.

Untuk rasio EBIT/TA $\left(X_{2}\right)$ perusahaan ini cukup baik dan selalu positif yang menunjukkan bahwa laba operasionalnya masih baik sepanjang 2009-2013 yang berarti 
bahwa pengelolaan aktiva perusahaan untuk menghasilkan laba operasi cukup baik dan stabil. Selanjutnya, rasio EBT/CL yang menujukkan kemampuan laba setelah bunga terhadap kwajiban lancar $\left(X_{3}\right)$ perusahaan TLKM selalu positif dan stabil. Sedangkan rasio efisiensi aset TLKM $\left(X_{4}\right)$ cukup stabil dengan rasio yang baik namun masih di bawah satu.

Dengan demikian dapat dihitung nilai z-score TLKM yang selalu di atas cut off berarti perusahaan ini selalu sehat dan jauh dari kebangkrutan. Maka investor dapat berinvestasi pada saham TLKM dengan aman dan menjanjikan di masa depan. Hal ini disukung oleh profitabilitas anak-anak perusahaannya terutama Telkomsel yang merajai industry ICT di Indonesia.

\section{SIMPULAN}

Pengujian model Springate yang dilakukan pada PT Bakrie Telecom Tbk (BTEL) pada periode 2009-2013 menunjukan hasil bahwa perusahaan ini mengalami financial distress yang semakin parah dan mengarah pada kebangkrutan. Sementara, PT Smartfren Tbk (FREN) juga mengalami masalah finansial yang mirip dengan BTEL sehingga diprediksikan mengalami financial distress dan potensi kebangkrutan. Permasalahan finansial BTEL dan FREN dimulai dari pendapatan (revenue) yang kurang baik dan diperparah oleh rendahnya efisiensi aset. Dengan demikian laba operasi (EBIT) kedua perusahaan tersebut terus menurun yang mengakibatkan kesulitan arus kas dan likuiditas yang akut. Semakin lama solvabilitas perusahaan-perusahaan tersebut juga semakin rendah sehingga kemampuan memenuhi kewajiban jangka panjangya semakin kecil dan berakibat memicu masalah struktur modal (financial distress) yang dapat membangkrutkan keduanya.

Pengujian yang dilakukan untuk PT XL Axiata Tbk menunjukkan bahwa perusahaan ini cenderung mengalami financial distress dan kebangkrutan, kecuali di 2010. Manajemen XL Axiata dinilai belum mampu meningkatkan profitabilitas perusahaan secara signifikan sehingga kerap timbul masalah likuiditas dan solvabilitas. Kondisi keuangan perusahaan ini kurang baik namun tidak separah BTEL dan FREN. Sementara itu, PT Inovisi Infracom, Tbk memiliki potensi financial distress dan kebangkrutan namun tidak terlalu serius dan dapat segera diatasi dengan baik. Secara umum kondisi keuangan Inovisi dalam kondisi aman dan relatif aman dari kebangkrutan. Manajemen diharapkan 
mampu meningkatkan kemampuan profitabilitas, likuiditas dan solvabilitas perusahaan agar menjauh dari zona kebangkrutan.

Adapun PT Indosat, Tbk mengalami financial distress dan kebangkrutan selama periode 2009-2013 yang disebabkan masalah likuiditas, profitabilitas dan solvabilitas yang semakin rendah. Namun masalah finansial Indosat belum seberat BTEL dan FREN sehingga masih memiliki potensi untuk mengatasi permasalahan keuangannya melalui peningkatan pendapatan dan efisiensi aset. Selanjutnya, analisis Springate untuk PT Telekomunikasi Indonesia dinilai tidak berpotensi mengalami masalah keuangan baik dari aspek likuiditas, profitabilitas efisiensi aset maupun solvabilitasnya selama periode 20092013. Dukungan pendapatan dan EBIT yang stabil dan memadai membuat likuiditas dan arus kas perusahaan cukup andal sehingga tidak memeiliki potensi kebangkrutan.

\section{DAFTAR PUSTAKA}

Altman, Edward I, Alessandro Danovi And Alberto Falini, 2012, Z-Score Models' Application To Italian Companies Subject To Extraordinary Administration.

Altman, Edward I., 1968, Financial Ratios, Discriminant Analysis and the Prediction of Corporate Bankruptcy, Journal of Finance, 23 September, 589-609.

Ayu, N., 2008, Perbandingan Analisis Prediksi Kebangkrutan Menggunakan Model Altman Pertama, Altman Revisi, dan Altman Modifikasi Dengan Ukuran dan Umur Perusahaan Sebagai Variabel Penjelas (Studi Pada Perusahaan Manufaktur Yang Terdaftar di Bursa Efek Indonesia). Jurnal Siasat Bisnis Vol. 13, No. 1.

Brimantyo, Harril. et.al. (2013). Penerapan Analisis Altman Z-Score Sebagai Salah Satu Alat Untuk Mengetahui Potensi Kebangkrutan Perusahaan Pada Perusahaan Telekomunikasi yang Listing di BEI Periode Tahun 2009-2011. Malang: Universitas Brawijaya.

Fanny, Margaretta dan Sylvia Saputra. (2000). Opini Audit Going Concern: Kajian Berdasarkan Model Prediksi Kebangkrutan, Pertumbuhan Perusahaan, Dan Reputasi Kantor Akuntan Publik (Studi Pada Emiten Bursa Efek Jakarta). SNA VIII. Solo. 15-16 September.

Devi Methili Purnajaya, Komang Dan Ni K. Lely A. Merkusiwati. (2014). Analisis Komparasi Potensi Kebangkrutan Dengan Metode Z - Score Altman, Springate, Dan Zmijewski Pada Industri Kosmetik Yang Terdaftar Di Bursa Efek Indonesia . Bali: Universitas Udayana. 
Kuncoro, A. W. (2011). Analisis Kebangkrutan Dengan Model Springate dan Zmijewski Pada PT Betonjaya Manunggal Tbk. Periode 2007-2011. Jakarta: Universitas Budi Luhur.

Kurniawanti, B. A. (2012). Analisis Penggunaan Altman Z-Score Untuk Memprediksi Potensi Kebangkrutan perusahaan Makanan Dan Minuman yang Terdaftar Di Bei Periode 20072011. Jakarta: Universitas Gunadarma.

Lukviaman, A. S. (2009). Perbandingan Analisis Prediksi Menggunakan Model Altman Pertama, Altman Revisi, dan Altman Modifikasi Dengan Ukuran dan Umur Perusahaan Sebagai Variabel Penjelas (Studi Pada Perusahaan Manufaktur Yang terdapat di Bursa Efek Indonesia). Jurnal Siasat Bisnis, Vol.13, No.1.

Saifi, Muhammad, Devi Farah dan Azizah Firda Mastuti. (2013). Altman Z-Score Sebagai Salah Satu Metode Dalam Menganalisis Estimasi Kebangkrutan Perusahaan. Universitas Brawijaya: Malang

Peter, Y. (2011). Analisis Kebangkrutan Dengan Metode Z-Score Altman, Springate dan Zmijewski Pada PT.Indofood Sukses Makmur Tbk. Periode 2005-2009.

Rahmawati, A. Y. (2010). Kebangkrutan Perusahaan Menggunakan Model Altman dan Zavgren Pada Perusahaan Food and Beverages. Jurnal The Winners, 11 (01). ISSN 1412-1212.

Santosa, Perdana Wahyu dan Ayat Hidayat, 2014, Riset Terapan: Teori dan Aplikasi, Penerbit Globastat, Jakarta.

Santoso, I. S. (2011). Analisis Kebangkrutan Dengan Menggunakan Metode Springate, Skripsi, Universitas Kristen Maranatha, Bandung.

Saputra, M. F. (2000). Opini Audit Going Concern: Kajian Berdasarkan Model Prediksi Kebangkrutan, Pertumbuhan Perusahaan, dan Reputasi Kantor Akuntan Publik (studi Pada Emiten Bursa Efek Jakarta). Solo.

Sawir, Agnes. (2001). Analisis Kinerja Keuangan dan Perencanaan Keuangan Perusahaan. Jakarta:PT Gramedia Pustaka Utama.

Springate, Gordon L.V. (1978). Predicting the Possibility of Failure in a Canadian Firm. M.B.A. Research Project, Simon Fraser University. January.

Subrahmanayan, K.R and Wild, John, 2010, Financial Statement Analysis, Mc Graw-Hill Education, USA.

Sukhemi. (2004). Analisis Rasio Keuangan Untuk Memprediksi Kebangkrutan. Jogjakarta: Universitas PGRI Jogjakarta.

Supardi. (2003). Validitas Penggunaan Z-Score Altman Untuk Menilai Kebangkrutan Perusahaan Perbankan Go public Di Bursa Efek Jakarta. Bandung: Universitas Padjajaran. 
Syamsul, A. A. (2008). Pemilihan Prediktor Delisting Terbaik (Perbandingan Antara The Zmijewski Model, The Altman Model, dan The Springate Model.: Universitas Islam Indonesia.

Syarifuddin, Amir. (2008). Ushul Fiqh. Jakarta: Kencana

Tribun News. (2014). Merger dan Akuisis Selamatkan Axis dari Kebangkrutan. http://www.tribunnews.com/bisnis/2014/02/17/merger-dan-akuisisi-selamatkan-axis-darikebangkrutan. (22 Desember 2014)

Van Horne, James and Wachowicz, John, 2009, Fundamental of Financial Management, Ed. 13th, Prentice-Hall, USA

Zmijewski, Mark. (1983). Predicting Corporate Bankruptcy: An Empirical Comparison of the Extant Financial Distress Models. Working paper. SUNY at Buffalo. 